\title{
PHILOSOPHY AND DEMOCRATIC PREJUDICE
}

\section{Preliminary Remarks}

Since men have organized themselves in polities, overcoming the state of nature, power has chosen to resort to principles to legitimize itself. Innumerable wars have been conducted in the name of noble goals, entire nations have been destroyed in the name of these goals. The prevailing power subsequently ruled by invoking its supposedly noble mission in the defence of humanity - albeit, in actual fact, the driving motive may have been what is nowadays referred to as the "national interest," a conglomerate of collective volitions, but certainly not a system of values that would transcend the actual will to power.

While, in earlier centuries, it has often been the role of religion (i.e. religious values) to justify the use of force and a polity's - or ruler's - claim to power, in the modern world religious beliefs have been replaced by the doctrine of democracy and, as its foundation, human rights. Since the late $20^{\text {th }}$ century, many wars have been fought in the name of democracy and the fundamental rights of the citizen. The doctrine of "humanitarian intervention" - or "Responsibility to Protect" (R2P) - is clear evidence of this trend that gained strength since the end of the cold war in particular. ${ }^{1}$ Régimes have been "changed"

1 For details see the author's analysis, The Concept of Humanitarian Intervention in the Context of Modern Power Politics: Is the Revival of the Doctrine of "Just War" Compatible with and entire regions were destabilized as result of such actions - with the consequence of perpetual conflict (instead of "Perpetual Peace" as envisaged by Immanuel Kant in his outline of a "republican" world order) (Kant, 1995) and the re-emergence of totalitarian systems of which the "Islamic State" is the most frightening phenomenon. ${ }^{2}$

It thus appears appropriate for philosophy to analyze and deconstruct one of the fundamental concepts in the name of which the global claim to power is legitimized in the post-cold war era. It is to be hoped that such an effort will contribute to more cautious and prudent action of state leaders and will make it more difficult to legitimize, and get support for, war at the international level.

\section{Terminology}

\section{A. The notion of democracy}

What is referred to as "democracy" in contemporary discourse is, in actual fact, and in most cases, a system of rule on behalf of the people, not by the people. This is in strict conceptual contradiction to the original Greek notion of $\delta \eta \mu о-\kappa \rho \alpha \tau i ́ \alpha$. It is a commonly held view that, unlike in ancient times, in our

the International Rule of Law? (Studies in International Relations, Vol. XXVI.) Vienna: International Progress Organization, 2001.

2 Thus, in the early $21^{\text {st }}$ century, we are again witnessing a return of religion, by way of reaction, as legitimizing factor in the realm of politics. 
modern, post-Enlightenment era, the $\delta \tilde{\eta} \mu \circ$ (people) is not a distinct group of privileged persons, excluding all others, but the community of all inhabitants (with the exception of foreigners) as citizens. In reality, however, "democracy" is essentially defined as parliamentary rule, i.e. as the exercise of power by a select group of individuals over the $\delta \tilde{\eta} \mu \mathrm{os}$. Popular rule in the original sense - by way of referendum - is, if at all, only admitted as exception.

Against this background, the terminology established in political science is rather misleading. The distinction between "direct" and "indirect" democracy creates the impresssion as if the democratic paradigm - originnally postulated in the ancient Athenian polity was compatible with action by proxy. "Rule" is either direct (genuine) or it does not exist at all. This was more clearly understood in the context of Kantian practical philosophy (in view of his notion of autonomy) (Kant, 1989, Critique of Practical Reason, Book I, Chapter $1, \S 8$; Foundations of the Metaphysics of Morals and, What Is Enlightenment?, p. 65.) or, more specifically, in Rousseau's doctrine of democracy: "La volonté ne se représente point: elle est la même, ou elle est autre; il n'y a point de milieu." 3 The will of the people cannot be represented (i.e. exercised by others on behalf of the citizen); in such a case, it ceases to exist. This also implies that the modern term participatory (or: direct) democracy is actually a pleonasm, wrongly making people believe that there can be genuine practices of democracy other than those of direct

3 Du Contrat Social ou principes du droit politique (1762), III, 15 /1762, quoted according to Oeuvres choisies. Paris: Classiques Garnier, 1954. agency of each and every individual as citizen. ${ }^{4}$

This "democratic prejudice," which has shaped contemporary politics at the global level, must be carefully scrutinized - if we are indeed committed to preserving the spirit of democracy, i.e. the democratic ideal. This is the legitimate role of the philosophy of politics - a form of "Ideologiekritik" that keeps distance from actual practice, critically reflects political stereotypes and, thus, is able and has the courage - to "speak truth to power."

What is commonly referred to as "democracy" is, in most cases, a system of representation for which the more appropriate Greek term would be ỏ $\lambda$ i $\alpha \rho \chi i ́ \alpha$ (oligarchy) which, however, lacks the legitimizing power of the prevalent term.

\section{B. The notion of representation}

In modern political discourse, the dominant doctrine is that of representation. According to its rarely questioned assumption, "democracy" - as explained above - means the power to decide on behalf of the people (citizens), not the people's power to decide. In this system, the political competence is vested in specially authorized office-holders (such as president, member of parliament, etc., depending on the respective constitutional provisions) who are understood to re-present (lit-

4 For details see also Hans Köchler, "Demokratie - Parlamentarismus - Menschenrechte. Philosophische Überlegungen zum 'demokratischen Vorurteil',' in: G. Prabitz and W. Schopper (eds.), Uni 2000. Zukunftsperspektiven universitärer Forschung und Lehre am Beispiel der Universität Innsbruck. Innsbruck: Haymon, 1990, pp. 51-61. 
erally: "make again present") the totality of the people ${ }^{5}$ and who exercise their authority by way of a "free" mandate, i.e. not bound by the will of others, including the electorate, but only by the dictates of their conscience - with the supposed aim to serve the common good as they - the representatives - understand it.

However, "democracy by representation" is based on fictitious premises that must be identified as such if one wants to understand the nature of most of our contemporary political systems. Those fictitious assumptions are:

1. That there exists a totality of the people as an ideal entity (ontological fiction in the Platonic sense, or a version of false idealism in the sphere of the collective);

2. that the representative is capable to act like an "ethereal being," without any consideration as to his/her personal interests and motivations (while, in reality, and in most cases, every deputy in parliament acts on party orders) (psychological fiction, stipulating an ideal person supposed to be able to act altruistically in an absolute sense);

3. that the will of the citizens, the source of any legitimate democratic order, can at all be represented by an individual or a group of individuals (i.e. that it can be made present as act of volition and source of the law) (normative fiction). The latter is a double fiction in the strict sense, implying (a) that there exists something like a "collective will" as an entity that can be represented, and (b)

\footnotetext{
Cf. the analysis of Carl Schmitt, Verfassungslehre (1928). Berlin: Duncker \& Humblot, 1954.
}

that this might be exercised by an individual on behalf of all. ${ }^{6}$

If connected to the doctrine of representation, the notion of popular sovereignty - as foundation of state sovereignty in the international realm ${ }^{7}$ - also becomes fictitious, a point which Hans Kelsen, the author of the Austrian Republic's first constitution after World War I, has also made clear (Kelsen, 1963, pp. 30ff).

\section{Quid Nunc? - Political Conclusions from Philosophical Disillusionment}

What follows from this deconstruction to use a fashionable term - of the democratic prejudice? Is it more than a futile exercise in Ideologiekritik, an abstract, non-consequential conceptual analysis? Under conditions of the so-called New World Order - i.e. the system of power relations after the collapse of the cold war's bipolar balance of power ${ }^{8}-$ a more

6 On the fictitious character of representation see the author's analysis, "Demokratietheorien im Schnittpunkt von Verfassung und politischer Wirklichkeit,“ in: A. Pelinka and H. Reinalter (eds.), Interdisziplinäre Demokratieforschung. (Series "Vergleichende Gesellschaftsgeschichte und politische Ideengeschichte der Neuzeit," Vol. 11.) Vienna: Braumüller, 1998, pp. 117-128.

7 On the conceptual connection between sovereignty and democracy see the author's lecture, "Sovereignty, Law and Democracy versus Power Politics," in: Current Concerns, No. 34, Zurich, 22 November 2013, Supplement, pp. 18-25.

8 For details see, inter alia, Hans Köchler, Democracy and the New World Order. (Studies in International Relations, Vol. XIX.) Vienna: International Progress Organization, 1993. 
precise use of terms will have multiple benefits for any polity that aspires to be "democratic":

(a) Conceptual clarification will help the public - the citizens - to avoid confusion over their actual status. Being able to precisely identify the factors of decisionmaking will enable the citizens to act rationally vis-à-vis their "representatives" instead of fatefully accepting their decisions.

(b) A precise terminology, not confusing democracy with oligarchy or autocracy, will make it more difficult for the holders of power to immunize their exercise of authority - because they will have to face a more mature citizenry. In this sense, precision is a kind of antidote to the abuses of power.

(c) Internationally, it will be more difficult to instrumentalize "democracy" to justify the use of force (as happened, for instance, in the cases of Iraq 2003 or Libya 2011) if an informed public understands that what is invoked in the justification of such interventions is not the right of each citizen to decide, but a kind of élite rule that is meant to serve the interests of the intervening power and, actually and more specifically, the lobbies and interest groups of that country.

While, under the ideological cover of representation and the free mandate, the real motives and interests of the political actors can be conveniently hidden, terminological precision and honesty about the exercise of power have a profoundly de-legitimizing ef$f e c t$ - domestically as well as internationally, and may, in the longer term, contribute to what is often described as democratization of society and state - and, subsequently, of the system of relations between states.

A more honest discourse on democracy, in the sense of not equating "representation" with "democracy" - or power with subordination to power, may also help to achieve a synthesis between idea and reality of politics - or between old-fashioned, but stubbornly persisting, realpolitik and the ideal of equality of states ("sovereign equality" as enshrined in the United Nations Charter) ${ }^{9}$ at the global level.

\section{Idea and Reality of Politics}

In the ideal world, freedom and the inalienable dignity of the human being mean that he/she should be able to take part in public life and jointly conduct the affairs of the community directly, without any intermediaries, and at an equal level. However, in the real - ever more complex - world of the collective organization of the will of human beings in states, large or small, the individual (out of organizational necessity) will have to delegate his/her authority to specially designated office-holders, a process which - if there are no corrective mechanisms such as referenda - is tantamount to his/her abdication as citizen. ${ }^{10}$ In that regard, it may be of interest to study the Swiss political practice, which can be

9 Article 2, Par. 1.

10 On the incompatibility of the democratic principle with representation see also, Robert Michels, Zur Soziologie des Parteiwesens in der modernen Demokratie: Untersuchungen über die oligarchischen Tendenzen des Gruppenlebens. Leipzig: Dr. Werner Klinkhardt, 1911, pp. 36ff. 
characterized as a kind of fusion of idealist and realist approaches in the organization of the popular will (Kriesi, 2005).

By using the proper terms in the description of the decision-making processes, we can avoid creating expectations that cannot be fulfilled and will unavoidably lead to political disillusionment. "Democratic fatigue" - a phenomenon ever more widespread also in the industrialized world ${ }^{11}$ - can best be countered by civic honesty, i.e. if we identify as "democratic" only those practices (i.e. forms of decision-making) where the individual can meaningfully participate in public life. The overcoming of "democratic prejudice" along the philosophical considerations briefly outlined here - will be the precondition for setting one's "democratic expectations" at arealistic and philosophically sound level.
Critique of a false idealism, indeed an idealistic fiction, of the community will be more conducive to a stable order of peace, domestically as well as internationally, than an attitude based on illusions and - ultimately false expectations.

\section{REFERENCES}

Kant, I. (1989). Critique of Practical Reason. New York: Macmillan.

Kant, I. (1995). Zum ewigen Frieden. (O. Höffe, Ed). Berlin: Akademie.

Kelsen, H. (1963). Vom Wesen und Wert der Demokratie (2nd ed.). Aalen: Scientia Verlag.

Kriesi, H. (2005). Direct Democratic Choice: The Swiss Experience. Lanham/Plymouth: Lexington Books.

11 See e.g. Carlo Mongardini, "Crisis and Transformation of Political Representation in Western Europe," in: Hans Köchler (ed.), The Crisis of Representative Democracy. Frankfurt a.M./Bern/New York: Peter Lang, 1987, pp. 115-125. 